\title{
Application of Android-Based Stress Meter as Stress Academic Indicator on College Student with Low Achievement Motivation
}

\author{
M. Mulawarman ${ }^{1}$, I. Ariffudin ${ }^{2}$, A. I. N.. Rahmawati ${ }^{3}$, M. E. Wibowo ${ }^{4}$, E Purwanto Pu $^{5}$ \\ A. Munandar ${ }^{6}$ \\ ${ }^{1,2,3,4,5,6}$ Faculty of Education Science, Universitas Negeri Semarang, Indonesia \\ ${ }^{1}$ Corresponding author: imam.counselor@students.unnes.ac.id
}

\begin{abstract}
Academic stress on college students often triggers a low level of achievement motivation for students. Today in the digital age, psychological measurement instruments are needed that can be quickly, effectively and efficiently used by college counselors. Based on this, it is necessary to apply an Android-based stress measurement instrument. The research for this initial study aims to implement in a limited area of Android version of stress measurement instruments with an acceptable level of acceptability criteria. Data were obtained from 30 students purposively using two measuring instruments. Stress identification instruments namely DASS-42 (Depression, Anxiety, and Stress Scale) with the value of reliability coefficient ( $\alpha$ Cronbach) of each variable respectively 0.91, 0.84, 0.90 and Achievement Motivation Scale (revised) with a reliability coefficient of 0.76 ( $\alpha$ Cronbach). The results show that the Android-based stress measurement instrument has a moderate level of acceptability. In addition, the results of the hypothesis test showed a correlation between stress levels and achievement motivation in college students. Thus, further coping strategies are needed to reduce stress levels which will be presented in the discussion.
\end{abstract}

Keywords: Android-Based Stress Meter, Stress Academic, Achievement Motivation

\section{Introduction}

The academic world is a world that triggers students to compete for achievements, not least for final year students. This situation is sometimes to be a poison for science prosecutors, the reason is not all of them have the same fighting power, so that students who have lack persistence and high fighting power tend to be susceptible to stress (Elias, Ping, \& Abdullah, 2011). This is supported by the results of Karaman \& Watson's (2017) study which says that stress due to academic activities on campus is one of the predictors of the decreasing level of student achievement motivation. Suspecting the phenomena that occur, it is necessary to make an early identification related to the level of student stress. When the stress level experienced by students is known, prevention of negative stress effects can be done, especially keeping students' achievement motivation in academic activities on campus.

Achievement motivation is a motivation that is intended to develop or demonstrate high abilities (Nicholl, 1984). There are two types of standards of success in achieving achievements, namely the achievements of others and / or their own achievements in the past. Individuals can be said to have high achievement motivation in the academic field when (1) task-choice, choosing activities to develop academic competence when leisure time; (2) persistence, tenacity to achieve goals; (3) effort, mobilizing all energy (physical and psychological) in learning (Purwanto, 2014).

As already explained, that academic stress can lead to a decrease in achievement motivation, it is very important to be identified earlier the level of academic stress. So, the number of low level of achievement motivation in the final semester students can be minimized. This is supported by the results of research which states that achievement motivation has a negative and weak correlation with stress, meaning that if individuals experience low achievement motivation, then it can be caused by high levels of academic stress (Elias, Ping \& Abdullah, 2011).

The identification needs to be done by using a psychological scale that has a high level of validity and reliability (Drummond, 2006). Thus, a psychological measuring tool was developed in the form of an Androidbased stress meter application (Ariffudin, 2016). This application adopts the DASS 42 (Depression, Anxiety and Stress Scale) instrument from Lovibond \& Lovibond (1995) to measure the level of academic stress experienced by students. The development of the Android-based stress meter application is 
an innovation in guidance and counseling as an adjustment to the current era of disruption. When students are able to realize the level of stress they are experiencing, it is expected that they can seek psychological help so that their achievement motivation to be able maintained.

This study aims to examine the acceptability of stress meter applications in students, so that it can be used in measuring student stress levels. In addition, this research seeks to uncover the correlation between stress and achievement motivation and other effects of stress as a divertion of stressors experienced.

\section{Method}

This study uses quantitative and qualitative designs for two different data. Quantitative design was used to test the acceptability of android-based stress meter applications (adopting the DASS instrument in it), identifying stress levels and achievement motivation, and testing the relationship between stress and achievement motivation. Then the qualitative design is used to determine the psychological dynamics of students who experience high stress and low achievement motivation.

The sample in this study was divided into two. At first 55 students majoring in guidance and counseling at Universitas Negeri Semarang who were taking the final semester were chosen to identify the level of achievement motivation. After the data was collected and identified only students who had low and medium achievement motivation levels were selected purposively as advanced participants. The screened participants are then given a stress meter application to determine the level of stress they have while testing the acceptability of the application.

Acceptability data is taken from a questionnaire with assessment criteria based on four categories of acceptability (utility standards, feasibility standards, property standards and accuracy standards) of the Joint Committee on Standards for Educational Evaluations (1994), in addition to the application of stress meters used to measure stress levels adopting the DASS instrument (Depression, Anxiety and Scale) 42 from Lovibond \& Lovibond (1995) which consists of three indicators namely stress, anxiety and depression. This instrumen also has been adapted in Indonesia version by Damanik
(2010). DASS 42 Has 42 statement items and 4 answer choices scala likert $(0=$ not agree to $3=$ very agree) with internal consistency ratio (reliability) of $0.91,0.84,0.90$ (Cronbach's alpha) for each variable. Example statement "I found it hard to calm down after something upset me". As for measuring the level of achievement motivation of students using the AMS (Achievement Motivation Scale) instrument from Lang \& Fries (2006) and consists of two indicators namely Hope for Success \& Fear of Failure. AMS has 10 statement items and 4 Likert scale answer choices $(1=$ low to $4=$ very high $)$ with a reliability score of .73 (Cronbach's Alpha). Examples of "I like the situation when I can show how great I am ".

The second sample was taken from students who had identified stress levels and achievement motivation. From the first number of samples, it was eliminated again to 8 students who had the highest stress level and the lowest percentage motivation. 8 of these participants were then interviewed to reveal the psychological dynamics they had experienced so far. Phenomenological design with thematic analysis is used to reveal and analyze qualitative data from students.

\section{Result and Discussion}

Acceptability test for stress meter application was carried out on 30 final semester students majoring in Guidance and Counseling Semarang State University (table 1). This amount is obtained from the results of purposive sampling aimed at students who are doing their final assignments at 2018/2019 of academic year and identified as having low achievement motivation.

A total of 28 students were identified as having low achievement motivation and the remaining 2 were identified as having moderate motivation (table 3). 30 students were then given a stress meter application to determine the level of academic stress they had. Based on the results from table 3, it can be seen that all participants experienced academic stress at a very high-low level. 
Table 1. Sosio demography Sociodemographics of Total Sample

\begin{tabular}{lllll}
\hline \multicolumn{1}{c}{$\begin{array}{c}\text { College Student } \\
(\mathrm{N}=30)\end{array}$} & N & $\begin{array}{c}\text { Percent } \\
\text { of Total }\end{array}$ & Mean & SD \\
\hline Sex & 13 & 57 & & \\
Male & 17 & 43 & & \\
Female & & & & \\
Age & 19 & 97 & 22,03 & 0,14 \\
$21-22$ & 1 & 03 & & \\
$22-23$ & & & & \\
Semester of Study & 19 & 97 & 7,04 & 0,28 \\
$7^{\text {th }}$ & 1 & 03 & & \\
$9^{\text {th }}$ & & & & \\
\hline
\end{tabular}

Table 1 shows that the majority of stress meter application users are women with an age range of 21-22 years. All participants who have tried using the stress meter application are then given a questionnaire to assess acceptability with 4 criteria (utility standards, feasibility standards, property standards and accuracy standards) adopted from the Joint Committee on Standards for Educational Evaluations (1994).

Table 2. Skor of Stress Meter's Acceptability Test

\begin{tabular}{|c|c|c|c|c|c|}
\hline \multirow[b]{2}{*}{$\begin{array}{l}\text { Colleg } \\
\text { e } \\
\text { Studen } \\
\text { ts } \\
(\mathrm{N}=30)\end{array}$} & \multicolumn{4}{|c|}{ Acceptability } & \multirow{2}{*}{$\begin{array}{l}\text { Perce } \\
\text { nt of } \\
\text { Total }\end{array}$} \\
\hline & $\begin{array}{l}\text { Utilit } \\
y\end{array}$ & $\begin{array}{l}\text { Feasibili } \\
\text { ty }\end{array}$ & $\begin{array}{l}\text { Accura } \\
\text { cy }\end{array}$ & $\begin{array}{l}\text { Proprie } \\
\text { ty }\end{array}$ & \\
\hline $\begin{array}{l}\text { Skor } \\
\text { Percen } \\
\text { t of } \\
\text { Total }\end{array}$ & .87 & .75 & .78 & .73 & .78 \\
\hline
\end{tabular}

Based on acceptability test results in Table 2, it can be seen that stress meter applications meet acceptability criteria with moderate category (score .78) with a utility score of $.81, .75$ feasibility score, accuracy score .78 , and propriety .73 so that it can be concluded that This stress meter application can be used to measure student stress levels.

Table 3 shows the level of stress and achievement motivation in students. The number of students who have very high stress levels is 6 students, high level of 5 students and moderate level of 15 students, and low level of 4 students. As explained, the average stress score is 24.97 and is in the medium category with $\mathrm{SD}=6.35$. In addition, this table also explains that there are 28 students who experience a low level of achievement motivation and 2 students are in the medium category with an average overall score of 17.13 which means low category.
Table 3. Students' Level of Stress and Achievemen Motivation

\begin{tabular}{|c|c|c|c|c|c|c|}
\hline \multirow{2}{*}{$\begin{array}{l}\text { College } \\
\text { Students } \\
(\mathrm{N}=30)\end{array}$} & \multicolumn{2}{|l|}{ Sex } & \multirow[t]{2}{*}{$\mathrm{N}$} & \multirow{2}{*}{$\begin{array}{l}\text { Perce } \\
\text { nt of } \\
\text { Total }\end{array}$} & \multirow[t]{2}{*}{ SD } & \multirow{2}{*}{$\begin{array}{l}\text { Mea } \\
\text { ns }\end{array}$} \\
\hline & $\begin{array}{l}\text { Mal } \\
\mathrm{e}\end{array}$ & $\begin{array}{l}\text { Femal } \\
\mathrm{e}\end{array}$ & & & & \\
\hline \multicolumn{7}{|l|}{$\begin{array}{l}\text { Level of } \\
\text { Stress }\end{array}$} \\
\hline Very High & 1 & 5 & 6 & .20 & $\begin{array}{l}6.3 \\
5\end{array}$ & 24.97 \\
\hline High & 7 & 8 & $\begin{array}{l}1 \\
5\end{array}$ & .17 & & \\
\hline Average & 2 & 3 & 5 & .50 & & \\
\hline Low & 3 & 1 & 4 & .13 & & \\
\hline Normal & & & 0 & & & \\
\hline Level of & & & & & & \\
\hline $\begin{array}{l}\text { Achievem } \\
\text { ent }\end{array}$ & & & & & & \\
\hline Motivatio & & & & & & \\
\hline$n$ & & & & & & \\
\hline Very High & & & 0 & 0 & 2.2 & 17.13 \\
\hline & & & & & 7 & \\
\hline High & & & 0 & 0 & & \\
\hline Average & 2 & 0 & 2 & .07 & & \\
\hline Low & 11 & 17 & 2 & .93 & & \\
\hline & & & 8 & & & \\
\hline
\end{tabular}

Correlation results in table 4 show a significant relationship between academic stress levels and student achievement motivation. The correlation coefficient shown by these two variables is negative and quite strong $(\mathrm{r}=-.552 ; \mathrm{p}<.01)$. This negative relationship explains if the level of academic stress experienced by students is high, the achievement motivation possessed by students will tend to decrease. In addition, if viewed from a gender perspective, there is no significant correlation between the level of academic stress or student achievement motivation. This shows that the high level of academic stress and the decreasing level of achievement motivation in students are not related to gender.

As the results of the analysis above, students with low levels of achievement motivation certainly have a cause, one of which is stress. Stress experienced by students can be said with academic stress (Hancock \& Szalma, 2018). Operationally, academic stress is the pressures experienced by students both physically and psychologically, which triggers the emergence of three major indicators, namely anxiety, stress, and depression (Paulson, Thilak, \& Sarada, 2017). These three things often trigger students to no longer be resilient in facing all challenges, will tend not to enjoy the reality or the burden of the task, 
blame the situation, so that academic and nonacademic achievement decreases (Hancock \& Szalma, 2018). Some of the effects of stress are included as a number of indicators in the emergence of low achievement motivation (Bonneville-Roussy et al, 2017).

Table 4. Correlation between Stress, Achievement Motivation and Gender

\begin{tabular}{|c|c|c|c|c|}
\hline \multicolumn{2}{|c|}{ College Students } & \multirow{2}{*}{$\begin{array}{l}\text { Acade- } \\
\text { mic } \\
\text { Stress }\end{array}$} & \multirow{3}{*}{$\begin{array}{l}\begin{array}{l}\text { Achievem } \\
\text {-ent }\end{array} \\
-.552^{* *}\end{array}$} & \multirow{3}{*}{$\begin{array}{l}\begin{array}{l}\text { Gend } \\
\text {-er }\end{array} \\
-.329\end{array}$} \\
\hline Academic & Pearson & & & \\
\hline \multirow[t]{3}{*}{ Stress } & Correlatio & & & \\
\hline & $\begin{array}{l}\text { n Sig. (2- } \\
\text { tailed) }\end{array}$ & 1 & .002 & .076 \\
\hline & $N$ & 30 & 30 & 30 \\
\hline Achievemen & Pearson & - & & \\
\hline \multirow[t]{4}{*}{ t Motivation } & Correlatio & $.552 *$ & & -.082 \\
\hline & $\begin{array}{l}\text { n Sig. (2- } \\
\text { tailed) }\end{array}$ & $*$ & 1 & .665 \\
\hline & & .002 & & \\
\hline & $\mathrm{N}$ & 30 & 30 & 30 \\
\hline \multirow[t]{3}{*}{ Gender } & $\begin{array}{l}\text { Pearson } \\
\text { Correlatio }\end{array}$ & -.329 & -.082 & 1 \\
\hline & $\begin{array}{l}\text { n Sig. (2- } \\
\text { tailed) }\end{array}$ & .076 & .665 & \\
\hline & $\mathrm{N}$ & 30 & 30 & 30 \\
\hline
\end{tabular}

Psychologically there are three indicators in determining that individuals in a low level of achievement motivation, namely (1) taskchoice, choose activities to develop academic competence during leisure time; persistence, tenacity to achieve goals; (3) effort, mobilize all energy (physical and psychological) in learning (Purwanto, 2014). Thus, it is necessary to identify early levels of stress in order to be able to control the level of achievement motivation.

Identification of stress levels can be done by providing a valid and reliable psychological scale. The quality of this psychological scale should also be adapted to current developments, so the emergence of stress meter application development and the results of this study reveal that the application of stress meters is a new breakthrough in this era of disruption, where the application tries not to limit the space and time between counselors and counselee. This application was designed by adopting the DASS instrument which was originally in the form of print media to be a psychological measurement tool based on Android applications. Acceptance test results show that this stress meter application can be accepted and used by users as an initial identification of stress levels.

The result of thematic analysis requires eight people as informants with the following classifications.

Table 5. The Demographic Data of the Informant

\begin{tabular}{|c|c|c|c|c|c|}
\hline $\begin{array}{c}\text { Informa } \\
\mathrm{nt}\end{array}$ & $\begin{array}{c}\text { Gend } \\
\text { er }\end{array}$ & $\begin{array}{c}\mathrm{Ag} \\
\mathrm{e}\end{array}$ & Status & $\begin{array}{l}\text { Stres } \\
\text { S } \\
\text { Level }\end{array}$ & $\begin{array}{c}\text { Achieveme } \\
\text { nt } \\
\text { Motivation } \\
\text { Level }\end{array}$ \\
\hline 1 & $\begin{array}{l}\text { Femal } \\
\mathrm{e}\end{array}$ & 21 & $\begin{array}{l}\text { Stude } \\
\text { nt }\end{array}$ & $\begin{array}{l}\text { Very } \\
\text { High }\end{array}$ & Low \\
\hline 2 & $\begin{array}{l}\text { Femal } \\
\text { e }\end{array}$ & 22 & $\begin{array}{l}\text { Stude } \\
\text { nt }\end{array}$ & $\begin{array}{l}\text { Very } \\
\text { High }\end{array}$ & Low \\
\hline 3 & $\begin{array}{l}\text { Femal } \\
\text { e }\end{array}$ & 22 & $\begin{array}{l}\text { Stude } \\
\text { nt }\end{array}$ & $\begin{array}{l}\text { Very } \\
\text { High }\end{array}$ & Low \\
\hline 4 & $\begin{array}{l}\text { Femal } \\
\text { e }\end{array}$ & 22 & $\begin{array}{l}\text { Stude } \\
\text { nt }\end{array}$ & $\begin{array}{l}\text { Very } \\
\text { High }\end{array}$ & Low \\
\hline 5 & Male & 23 & $\begin{array}{l}\text { Stude } \\
\text { nt }\end{array}$ & $\begin{array}{l}\text { Very } \\
\text { High }\end{array}$ & Low \\
\hline 6 & Male & 21 & $\begin{array}{l}\text { Stude } \\
\text { nt }\end{array}$ & $\begin{array}{l}\text { Very } \\
\text { High }\end{array}$ & Low \\
\hline 7 & Male & 21 & $\begin{array}{l}\text { Stude } \\
\text { nt }\end{array}$ & $\begin{array}{l}\text { Very } \\
\text { High }\end{array}$ & Low \\
\hline 8 & Male & 22 & $\begin{array}{l}\text { Stude } \\
\mathrm{nt}\end{array}$ & $\begin{array}{l}\text { Very } \\
\text { High }\end{array}$ & Low \\
\hline
\end{tabular}

Here are the results of the thematic analysis contained in the table 6 .

Table 6. The Result of Thematic Analysis

\begin{tabular}{|c|c|c|}
\hline $\begin{array}{l}\text { Main } \\
\text { Theme }\end{array}$ & Sub Theme & Coding \\
\hline $\begin{array}{l}\text { Internet } \\
\text { Overuse }\end{array}$ & $\begin{array}{l}\text { Gratificaion } \\
\text { (Time, } \\
\text { Application) } \\
\text { Cognitive } \\
\text { Preoccupation }\end{array}$ & $\begin{array}{l}\text { Spending time for } \\
\text { online activity } \\
\text { Preoccupied the } \\
\text { thought of using } \\
\text { internet } \\
\text { Thinking more and } \\
\text { more when offline }\end{array}$ \\
\hline $\begin{array}{l}\text { Self- } \\
\text { regulation }\end{array}$ & $\begin{array}{l}\text { Self-control } \\
\text { Mood } \\
\text { Regulation }\end{array}$ & $\begin{array}{l}\text { Difficult to control } \\
\text { the desire to use } \\
\text { internet } \\
\text { Angry when } \\
\text { disturbed } \\
\text { Blaming }\end{array}$ \\
\hline $\begin{array}{l}\text { Negative } \\
\text { Outcome }\end{array}$ & $\begin{array}{l}\text { Academic } \\
\text { Performance }\end{array}$ & $\begin{array}{l}\text { Low academic } \\
\text { motivation } \\
\text { Procrastination }\end{array}$ \\
\hline & $\begin{array}{l}\text { Physical } \\
\text { Symptoms }\end{array}$ & $\begin{array}{l}\text { Un-responsibility } \\
\text { when doing task } \\
\text { Headache } \\
\text { Not excited with all } \\
\text { things }\end{array}$ \\
\hline
\end{tabular}

Academic stress experienced by final students raises a variety of negative types, both academically and non-academically (Hancock 
\& Szalma, 2018). This is because of stress that will be stressed by the burden of responsibility they must do. As a result, students who experience stress begin to bring new negative behaviors both physically and psychologically, such as becoming more irritable, spending time on activities that are just to inspire, to carry out responsibilities, to be uninspired, not motivated etc. The explanation is supported by the results of research which states that individuals who emphasize stress will decrease in their academic performance, social life, regulation of emotions and even depression (Denovan \& Macaskill, 2017; Elias, Ping, \& Abdullah, 2011; Webster-Stratton \& Hammond, 1988 )

Table 6 shows that students who are in the midst of academic stress bring new behaviors which are contained in three themes. These themes are obtained from the results of coding in the interview process. The three themes are internet overuse, self-regulation, and negative outcomes

The emergence of internet overuse in stressed students is merely a form of transfer (Souza, Manish, \& S, 2018). Stressed individuals intentionally try to get out of their stress zones and choose to use the current media, the internet. The use of the internet also varies, to chat with close relatives and friends, access certain sites, and use it for status updates on social media or just to spend time looking for entertainment. This accident made them negligent that their internet usage has exceeded the reasonableness time limit so that if it continued it would have an impact on the problem of internet use or problematic internet use (Chong, Chye, Huan, \& Ang, 2014).

Furthermore regarding self-regulation, why self-regulation can be the theme in this study? This is because students who are stressed will tend not to easily control their mood or emotions so that they often vent with activities that harm themselves and others. As stated in table 6, self-regulation appears followed by difficulties in self-control, irritability and anger and leads to blaming themselves and others. The statement was supported by the results of research that revealed a correlation between stress and low self-regulation which led to decreased selfpotential (Hancock \& Szalma, 2018; Saleh, Camart, \& Romo, 2017)

In addition, negative outcomes appeared in table 6 where this theme represents low academic performance including procrastination, low academic motivation, decreased learning achievement and neglect of responsibilities and physical symptoms such as headaches, laziness, and lack of enthusiasm. These results are in accordance with the results of previous research which states that individuals with high stress levels will trigger health problems (Heissel, Levy, \& Adam, 2017) and decreased academic performance (Paulson, Thilak, \& Sarada, 2017). Following the interview results as a basis for determining the coding in table 6 .

\section{Internet Overuse}

The internet is an important part of life, especially for students. The absence of restrictions in usage becomes their main factor to continue to use it in the excess timeframe. In addition, students who are experiencing stress will divert their problems by accessing the internet or just playing smartphones, laptops, or online games. This can be seen from the results of interviews with a number of informants.

"If I'm stressed, I have played games, because in my opinion it's a fun activity"

[informant 1]

"When I was late, stressed, and could not think what I should do, I streamed Korean films until the day was strong and not out of boarding"

[informant 2]

"Contacting people who can relieve my stress all day long is the right way"

[informant 3]

"Seeing YouTube continuously can be a code if I am stressed, Sis, and finally continuity and become lazy to continue my tasks"

[informant 8]

\section{Mood Regulation}

Students who experience stress, of course, get various kinds of pressures that cannot be passed. As a result it affects their ability to control themselves and emotions. This is included in the results of interviews that explain explicitly how their emotional dynamics are experiencing stress. 
"When I got various pressures, both from parents who wanted me to quickly graduate, and various assignments from the lecturer made me feel sad, cry, and angry because I felt unable to finish it immediately"

\section{[informant 2]}

"I'm lazy to do anything, my mood immediately changes and I don't want to be disturbed by others when I'm stressed"

[informant 5]

"I have a headache and blame everyone who causes me to be stressed and constantly grumbling"

[informant 8]

\section{Negative Outcome}

Stress can also have a negative impact on individual outcomes. The following are the results of interviews with participants related to the direct impact of experiencing stress. say I'm stressed"

"A lot of my work is neglected when I [informant 5]

"My motivation to be better than my friends decreased when I was stressed, so it was useless"

[informant 6]

duty"

"I became easy to forget to do my

[informant 7]

"I want to run away from my responsibilities, sometimes and easily give up" [informant 8]

\section{Conslusion}

Students' academic stress levels can in fact be measured using stress meter applications, both independently and with the help of counselors. Broadly speaking, this application has passed the acceptance test so that it can identify how high the level of academic stress experienced by final year students. In addition, there is a fairly high correlation between stress levels and achievement motivation. This shows that the higher the level of stress, the lower the level of achievement motivation. Other results also reveal that students who tend to experience high stress and low achievement motivation will divert their attention to seeking out activities. One of them is the use of the internet to just spend leisure time and seek entertainment, but in a relatively long period of time.

This study has limitations to reveal the existence of risk factors related to internet use while experiencing stress. Excessive internet use may be a reinforcement or impact of stress. This shows that stress levels can trigger problems in internet use. Therefore, the next research is expected to be able to reveal the relationship between academic stress experienced by final year students with excessive internet use, as well as the handling of counseling as a preventive and curative form.

\section{Refferences}

Ariffudin, I. (2016). Pengembangan Software Stress Meter Pada Siswa Kelas 10 SMAN 2 Kediri. Jurnal BK UNESA, Vol. 6, No.2

Bonneville-Roussy, A., Evans, P., VernerFilion, J., Vallerand, R. J., \& Bouffard, T. (2017). Motivation and Coping with The Stress of Assessment: Gender Differences In Outcomes for University Students. Contemporary Educational Psychology. 48, 28-42. http://dx.doi.org/10.1016/j.cedpsych.201 6.08 .003

Chong, W. H., Chye, S., Huan, V. S., \& Ang, R. P. (2014). Generalized problematic Internet use and regulation of social emotional competence: The mediating role of maladaptive cognitions arising from academic expectation stress on adolescents. Computers in Human Behavior, 38, 151-158. https://doi.org/10.1016/j.chb.2014.05.023

Damanik, E. . (2010). The Measurement of Reliability, Validity, Items Analysis and Normative Data of Depression Anxiety Stress Scale (DASS).

Denovan, A., \& Macaskill, A. (2017). Stress and Subjective Well-Being Among First Year UK Undergraduate Students. Journal of Happiness Studies, 18(2), 505-525. https://doi.org/10.1007/s10902016-9736-y 
Drummond, R. J, \& Jones, K. D. (2006). Assessment Procedures for Counselor and Helping Professionals.New Jersey, USA: Pearson Education, Inc.

Elias, H., Ping, W. S., \& Abdullah, M. C. (2011). Stress and academic achievement among undergraduate students in Universiti Putra Malaysia. Procedia Social and Behavioral Sciences, 29, 646655.

https://doi.org/10.1016/j.sbspro.2011.11. 288

Hancock, P. A., \& Szalma, J. L. (2018). Perfomance Under Stress. USA.

Lang, J. W. B., \& Fries, S. (2006). A revised 10-item version of the Achievement Motives Scale: Psychometric properties in german-speaking samples. European Journal of Psychological Assessment, 22(3), 216-224. http://dx.doi.org/10.1027/10155759.22.3.216

Lovibond, P. F., \& Lovibond, S. H. (1995). The structure of negative emotional states: Comparison of the Depression Anxiety Stress Scales (DASS) with the Beck Depression and Anxiety Inventories. Behaviour Research and Therapy, 33(3), 335-343. http://dx.doi.org/10.1016/00057967(94)00075-U

Karaman, M. A., \& Watson's, J. C. (2017). Examining Association among Achievement Motivation, Locus of Control, Academic Stress, and Life Satisfaction: A Comparison of U.S. and International Undergraduate Students. Personality and Individual Differences, 111, 106-110. doi: 10.1016/j.paid.2017.02.006.

Nicholls, J. G. (1984). Achievement motivation: Conceptions of ability, subjective experience, task choice, and performance. Psychological Review, 91(3), 328-346.

Heissel, J. A., Levy, D. J., \& Adam, E. K. (2017). Stress, Sleep, and Performance on Standardized Tests: Understudied Pathways to the Achievement Gap. AERA Open, 3(3), 233285841771348. https://doi.org/10.1177/23328584177134 88

Paulson, S., Thilak, \& Sarada. (2017). Academic Stress Among High School Students in Thalassery Educational Block, Kerala: a Cross Sectional Study. National Journal of Research in Community Medicine. Sup. Issue, 6(1), 73-76. Retrieved from http://www.commedjournal.in/article/Vol ume6SupIssue1July2017/fulltext/15NJR CM_Tilak Vol.6. Sup. Issue 1_2017.pdf

Saleh, D., Camart, N., \& Romo, L. (2017). Predictors of stress in college students. Frontiers in Psychology, 8(JAN), 1-8. https://doi.org/10.3389/fpsyg.2017.00019

Schunk, D.H., Pintrich, P.R., \& Meece, J. L. (2008). Motivation in Education, Theory, Research, and Applications. Third Edition. New Jersey: Pearson Education, Inc.

Souza, L. D., Manish, S., \& S, S. R. M. (2018). Relationship between Academic Stress and Internet Addiction among College Students, $6(2)$. https://doi.org/10.25215/0602.010

Stufflebeam, D. L., Bunda, M. A., Ridings, J. M., Rodosky, R. J., Sanders, J. R., Shinkfield, A. J., et al. (1981). Standards for Evaluations of Educational Programs, Projects, and Materials. New York, NY: McGraw-Hill Book Company

Webster-Stratton, C., \& Hammond, M. (1988). Maternal depression and its relationship to life stress, perceptions of child behavior problems, parenting behaviors, and child conduct problems. Journal of Abnormal Child Psychology, 16(October), 299-315. https://doi.org/10.1007/BF00913802.

Wigfield, A., \& Eccles, J. S. (2002). Development of Achievement Motivation. San Diego, CA: Academic Press. 